\title{
Pengawasan Majelis Pengawas Daerah terhadap Notaris setelah berlakunya Undang- Undang No. 2 Tahun 2014 tentang Perubahan atas Undang-Undang No 30 Tahun 2004 tentang Jabatan Notaris.
}

\author{
Muhammad Haris \\ Fakultas Syariah dan Ekonomi Islam IAIN Antasari Jl . A. Yani Km. 4,5 Banjarmasin \\ Email :mharis_sh@yahoo.com
}

\begin{abstract}
The Notary is a public official who was appointed by the Minister. Notaries are authorized officer to make authentic act of the civil. With this relationship beetwen the notary and the community, it would require a Notary professional supervision. Supervision of the Notary conducted by the Regional Supervisory Council who was inaugurated by the Minister as specified in the Notary Act. After the enactment of The Law Number 2 Year 2014 about The Amendment to Law Number 30 Year 2014 concerning Notary, there are some changes in regulations about supervision and guidance that will be undertaken by the Regional Supervisory Council. This law says that supervision of the Notary conducted by the Regional Supervisory Council, while the development under the authority of the Regional Supervisory Council before is now a Notary Honorary Council authority.
\end{abstract}

Abstrak: Notaris merupakan pejabat umum yang dilantik oleh Menteri. Notaris adalah pejabat yang berwenang untuk membuat akta otentik dalam lingkup keperdataan. Adanya hubungan Notaris dengan masyarakat ini, maka diperlukan sebuah pengawasan profesi Notaris. Pengawasan terhadap Notaris meliputi Jabatan Notaris dan juga perilaku Notaris. Pengawasan terhadap Notaris dilakukan oleh Majelis Pengawas Daerah yang di lantik oleh Menteri sebagaimana ditentukan dalam UndangUndang Jabatan Notaris. Setelah di berlakukannya Undang-Undang No. 2 Tahun 2014 tentang Perubahan atas Undang-Undang No. 30 Tahun 2014 tentang Jabatan Notaris, terdapat beberapa perubahan ketentuan yang mengatur pengawasan dan pembinaan yang di lakukan oleh Majelis Pengawas Daerah. Pengawasan terhadap Notaris dilakukan oleh Majelis Pengawas Daerah, sedangkan pembinaan yang sebelumnya juga kewenangan Majelis Pengawas Daerah sekarang menjadi kewenangan Majelis Kehormatan Notaris.

Kata Kunci: Pengawasan, Majelis Kehormatan Daerah, Notaris

\section{Pendahuluan}

Profesi Notaris di Indonesia mempunyai sejarah yang cukup tua. Notaris sudah ada di Indonesia sejak abad ke - 17, atau lebih tepatnya sejak tanggal 27 Agustus 1620 Melchior Kerchem menjabat sebagai Notaris pertama di Indonesia ${ }^{1}$. Pada masa itu Notaris tidak memiliki kebebasan seperti sekarang karena merupakan pegawai dari Oost Indie ${ }^{2}$, berbeda dengan keadaan sekarang dimana Notaris adalah seorang pejabat umum yang mandiri. Notaris merupakan suatu pekerjaan dengan keahlian khusus yang menuntut pengetahuan luas serta tanggung jawab yang berat untuk melayani kepentingan umum. Inti tugas Notaris adalah mengatur secara tertulis dan otentik hubungan hukum antara para pihak yang secara mufakat meminta jasa Notaris.

\footnotetext{
GHS Lumban Tobing, 1983, Peraturan Jabatan Notaris, cet.III, Erlangga, Jakarta hlm. 15.

2 Ibid, hlm. 17.
}

Sebelumnya Profesi Notaris di atur di dalam Undang-Undang No. 30 Tahun 2004 tentang Jabatan Notaris. Setelah hampir 10 tahun untuk menyesuaikan perkembangan yang ada dimasyarakat pengaturan Notaris masuk ke dalam tatanan baru dengan adanya perubahan terhadap Undang-Undang Jabatan Notaris. Pada saat ini Notaris diatur dalam Undang-Undang No. 2 tahun 2014 tentang perubahan atas Undang- Undang No. 30 Tahun 2004 tentang Jabatan Notaris. Menurut Pasal 1 UndangUndang No. 2 tahun 2014, Notaris adalah pejabat umum yang berwenang untuk membuat akta otentik dan kewenangan lainnya sebagaimana dimaksud dalam undang-undang ini atau berdasarkan undang-undang lainnya. Dari Pasal ini terlihat sebuah perbedaan dengan pada masa awal Notaris di Indonesia. Notaris bukan lagi pegawai pemerintah melainkan pejabat umum yang mandiri yang memiliki kewenangan dalam membuat akta otentik sepanjang untuk pembuatan akta tersebut tidak dikecualikan kepada pejabat lain. Seiring dengan 
pentingnya Notaris dalam kehidupan masyarakat khususnya dalam pembuatan akta otentik yang digunakan sebagai alat bukti, maka Notaris mempunyai kedudukan sebagai pejabat umum yang berwenang membuat akta otentik dan sekaligus merupakan perpanjangan tangan pemerintah.

Secara administratif, Notaris memiliki hubungan dengan negara dalam hal pemerintahan. Salah satunya adalah berkaitan dengan pengangkatan dan pemberhentian Notaris. Menurut Komar Andasasmita, bentuk atau corak Notaris dapat dibagi menjadi 2 (dua) kelompok utama yakni: ${ }^{3}$

Notariat functional, hal mana wewenangwewenang pemerintah didelegasikan (gedelegeerd) dan demikian itu diduga mempunyai kebenaran isinya, mempunyai kekuatan bukti formal dan mempunyai daya/ kekuatan eksekusi. Di negaranegara yang menganut bentuk notariat ini terdapat pemisahan yang keras antara wettelijke dan niet wetteljike, wekzaambeden yaitu pekerjaanpekerjaan yang didasarkan undangundang/hukum dan yang tidak/bukan dalam notariat. Notariat profesional, dalam kelompok ini walaupun pemerintah mengatur tentang organisasinya tetapi akta-akta Notaris ini tidak mempunyai akibat-akibat khusus tentang kebenarannya, kekuatan bukti demikian kekuatan eksekutorialnya.

Kehadiran institusi Notaris di Indonesia perlu dilakukan pengawasan oleh pemerintah. Adapun yang merupakan tujuan dari pengawasan agar para Notaris ketika menjalankan tugas jabatannya memenuhi semua persyaratan yang berkaitan dengan pelaksanaan tugas jabatan Notaris, demi untuk pengaman kepentingan masyarakat, karena Notaris diangkat oleh pemerintah, bukan untuk kepentingan diri Notaris sendiri melainkan untuk kepentingan masyarakat yang dilayaninya.

Dalam menjalankan fungsi dan tanggung jawabnya sebagai pejabat umum, tidak jarang Notaris berurusan dengan proses hukum. Pada proses hukum ini Notaris harus memberikan keterangan dan kesaksian menyangkut isi akta yang dibuatnya. Dengan diletakkannya tanggung jawab secara hukum dan etika kepada Notaris, maka kesalahan yang sering terjadi pada Notaris lebih banyak disebabkan oleh keteledoran Notaris tersebut, karena hal tersebut tidak mengindahkan aturan hukum dan nilai-nilai etika.

Komar Andasasmita, 1981, Notaris I, Sumur, Bandung, hlm. 12
Sebagai konsekuensi logis seiring dengan adanya tanggung jawab Notaris kepada masyarakat, maka haruslah dijamin adanya pengawasan dan pembinaan terus menerus agar Notaris selalu sesuai dengan kaidah hukum yang mendasari kewenangannya dan dapat terhindar dari penyalahgunaan kewenangan atau kepercayaan yang diberikan. Agar nilai-nilai etika dan hukum yang seharusnya dijunjung tinggi oleh Notaris dapat berjalan sesuai undangundang yang ada, maka sangat diperlukan adanya pengawasan.

Adapun tujuan pengawasan Notaris adalah memenuhi persyaratan-persyaratan dan menjalankan tugasnya sesuai dengan ketentuanketentuan dalam perundang-undangan yang berlaku demi pengaman kepentingan masyarakat umum, sedangkan yang menjadi tugas pokok pengawasan Notaris adalah agar segala hak dan kewenangan maupun kewajiban yang diberikan kepada Notaris dalam menjalankan tugasnya sebagaimana yang diberikan oleh peraturan dasar yang bersangkutan, senantiasa dilakukan di atas jalur yang telah ditentukan bukan saja jalur hukum tetapi juga atas dasar moral dan etika profesi demi terjaminnya perlindungan dan kepastian hukum bagi masyarakat..

Pengawasan Notaris sebelum berlakunya Undang-Undang No. 2 tahun 2014 dilakukan oleh Pengadilan Negeri dalam hal ini oleh hakim, namun setelah keberadaan Pengadilan Negeri diintegrasikan satu atap di bawah Mahkamah Agung maka pengawasan dan pembinaan Notaris beralih ke Departemen Hukum dan HAM Republik Indonesia. Pada dasarnya yang mempunyai wewenang melakukan pengawasan dan pemeriksaan terhadap Notaris adalah Menteri Hukum dan HAM mempunyai tugas yang dalam pelaksanaanya Menteri membentuk Majelis Pengawas Notaris. Menteri sebagai kepala Departemen Hukum dan HAM mempunyai tugas membantu Presiden dalam menyelenggarakan sebagian urusan pemerintah di bidang Hukum dan HAM.

Mekanisme pengawasan yang dilakukan secara terus menerus terhadap Notaris di dalam menjalankan tugas dan jabatannya sekarang dilaksanakan berdasarkan Undang-Undang No. 2 tahun 2014 tentang perubahan atas UndangUndang No. 30 Tahun 2004 tentang Jabatan Notaris, dan Peraturan Menteri Hukum dan HAM Republik Indonesia Nomor M.02.PR.08.10 Tahun 2004 Tentang Tata Cara Pengangkatan Anggota, Pemberhentian Anggota, 
Susunan Organisasi, Tata Kerja, dan Tata Cara Pemeriksaan Majelis Pengawas. Dalam ketentuan Undang-Undang No. 2 Tahun 2014 tentang perubahan atas Undang-Undang No. 30 Tahun 2004 tentang Jabatan Notaris, terdapat banyak perubahan mengenai Kewenangan Majelis Pengawas Daerah dalam melakukan pengawasan dan pembinaan terhadap Notaris.

\section{Pengawasan Notaris di Indonesia}

Notaris sebagai pejabat umum menjalankan suatu fungsi sosial yang sangat penting, yang meliputi kehidupan masyarakat pada umumnya, yang mana masyarakat meminta nasehat-nasehat dari Notaris mengenai isi dari akta-akta yang dibuat oleh Notaris. Notaris juga memberikan nasehat-nasehat dan petunjuk-petunjuk sebagaimana dimaksud dari para pihak yang bersangkutan, dengan mengindahkan peraturanperaturan dalam perundang-undangan yang berlaku sehingga dapat diwujudkan dengan sebaik-baiknya dan sedapat mungkin menghindarkan terjadinya perselisihanperselisihan

Dalam menjalankan tugas dan jabatannya Notaris mempunyai tugas untuk membuat akta otentik bagi masyarakat yang membutuhkan, akta otentik yang dibuat oleh Notaris adalah merupakan suatu pembuktian yang sempurna yang melahirkan suatu kepastian hukum apabila sewaktu-waktu terjadi perselisihan di antara para pihak yang membuat dan membutuhkan akta tersebut.

Sebagaimana layaknya seorang manusia yang tidak luput dari kesalahan dan kekhilafan. Notaris juga adalah manusia, sehingga Notaris juga bisa saja berbuat kesalahan dalam menjalankan tugas dan jabatannya sebagai pejabat umum. Oleh karena tugas dan jabatannya sebagai pejabat umum yang berwenang untuk membuat akta otentik, dan demi kepentingan masyarakat banyak maka untuk menghindari penyalahgunaan dan penyimpangan tugas dan jabatannya, bagi Notaris terutama dalam pembuatan akta agar tidak bertentangan dengan peraturan perundang-undangan yang berlaku.

Pada awalnya pengawasan Notaris berdasarkan Undang-undang Nomor 14 Tahun 1970 tentang ketentuan-ketentuan Pokok Kekuasaan Kehakiman, bahwa Departemen Kehakiman mempunyai otoritas terhadap organisasi, administrasi dan finansial pengadilan, termasuk di dalamnya pengawasan terhadap Notaris. Dalam Bab II Keputusan Bersama
Ketua Mahkamah Agung dan Menteri Kehakiman Republik Indonesia Tahun 1985 dimana disebutkan tentang ruang lingkup pengawasan Notaris, yaitu :

Pasal 2 ayat (1) berbunyi :

"Pelaksanaan pengawasan sehari-hari atas para Notaris dan akta-aktanya dilakukan oleh Ketua Pengadilan Negeri setempat dan selanjutnya secara hirarkhis dilakukan oleh Ketua Pengadilan Tinggi, Ketua Mahkamah Agung dan Menteri Kehakiman".

Ayat (2) berbunyi :

"Pengawasan tersebut ayat (1) dilakukan sejajar dengan pengawasan menurut jalur justisial yang telah diatur dalam peraturan Jabatan Notaris dan peraturan perundang-undangan lainnya sepanjang mengenai penyelenggaraan tugastugas Notaris.

Ayat (3) berbunyi :

Pengawasan tersebut ayat (1) bersifat membimbing dan membina yang diantaranya mewujudkan dengan diadakannya pertemuanpertemuan berkala oleh Ketua Pengadilan Negeri dengan para Notaris atau organisasi profesi Notaris di daerahnya".

Ayat (4) berbunyi :

"Para Ketua Pengadilan dari lain lingkungan peradilan membantu dalam pengawasan tersebut ayat (1) dengan menyampaikan hal-hal yang perlu kepada Ketua Pengadilan Negeri yang daerah hukumnya meliputi tempat kedudukan Notaris yang bersangkutan untuk ditangani.

Setelah Undang-undang Nomor 35 Tahun 1999 tentang Perubahan Atas Undang-undang Nomor 14 Tahun 1970 tentang Ketentuanketentuan Pokok Kekuasaan Kehakiman tersebut kemudian dicabut dan digantikan dengan Undang-undang Nomor 4 Tahun 2004 tentang Kekuasaan Kehakiman, yang pada intinya bahwa kekuasaan dilakukan oleh sebuah Mahkamah Agung dan badan peradilan yang berada di bawahnya dan oleh sebuah Mahkamah Konstitusi, kemudian organisasi, administrasi dan finansial dalam lingkungan peradilan peradilan berada di bawah kekuasaan dan kewenangan Mahkamah Agung dan Organisasi, administrasi finansial Mahkamah Konstitusi berada di bawah kekuasaan dan kewenangan Mahkamah Konstitusi, maka berdasarkan Undang-undang Nomor 4 Tahun 2004 tentang kekuasaan Kehakiman, Departemen Kehakiman sudah tidak mempunyai otoritas lagi terhadap organisasi, administrasi dan finansial pengadilan. 
Berdasarkan Undang-Undang Nomor 4 Tahun 2004 tentang Kekuasaan kehakiman yang baru tersebut, secara substansi Departemen Kehakiman q.q Menteri Kehakiman sudah tidak lagi mempunyai otoritas untuk melakukan pengawasan terhadap Notaris. Tapi pengawasan Notaris tersebut menjadi otoritas penuh badan peradilan, hal ini sesuai dengan Pasal 54 ayat (1) Undang-undang Nomor 8 Tahun 2004 tentang Perubahan atas Undang-undang Nomor 2 Tahun 1986 tentang Peradilan Umum, sedangkan Menteri Kehakiman dapat melakukan tindakan terhadap Notaris berdasarkan laporan Ketua Pengadilan Negeri dan setelah mendengar pendapat dari organisasi Notaris.

Ketentuan sebagaimana yang termaktub dalam Pasal 54 tersebut di atas telah dicabut dan dinyatakan tidak berlaku lagi berdasarkan Pasal 91 ayat (4) Undang Jabatan Notaris. Berdasarkan Undang-Undang Jabatan Notaris tersebut pengawasan Notaris memasuki babak baru, dimana pengawasan tidak hanya dari Notaris saja akan tetapi juga dari unsur pemerintah (Departemen Hukum dan Hak Asasi Manusia ) dan akademis bidang hukum. ${ }^{4}$

Dalam setiap organisasi terutama dalam organisasi pemerintahan fungsi pengawasan adalah sangat penting, karena pengawasan adalah suatu usaha untuk menjamin adanya kearsipan antara penyelenggara tugas pemerintahan oleh daerah-daerah dan oleh pemerintah dan untuk menjamin kelancaran penyelenggaraan pemerintahan secara berdaya guna dan berhasil guna. ${ }^{5}$ Pengawasan adalah salah satu fungsi dasar manajemen yang dalam bahasa Inggris disebut "controlling". Dalam bahasa Indonesia, fungsi controlling itu mempunyai dua padanan yaitu pengawasan dan pengendalian.

Pengawasan dalam hal ini adalah pengawasan dalam arti sempit, yaitu segala usaha atau kegiatan untuk mengetahui dan menilai kenyataan yang sebenarnya tentang pelaksanaan tugas atau pekerjaan, apakah sesuai dengan yang semestinya atau tidak, sedangkan pengendalian pengertiannya lebih forceful daripada pengawasan, yaitu sebagai segala usaa atau kegiatan untuk menjamin dan mengarahkan agar pelaksanaan

4 Majalab Renvoi Nomor 10.22 II tanggal 3 Maret 2005, hlm. 36

5 Viktor M Situmorang dan Cormentyna Sitanggang, 1993, Hukum Administrasi Pemerintahan di Daerah, Sinar Grafika, Bandung, hlm 233 tugas atau pekerjaan berjalan dengan yang semestinya. ${ }^{6}$

Pengertian dasar dari pengawasan adalah segala usaha atau kegiatan untuk mengetahui dan menilai kenyataan yang sebenarnya tentang pelaksanaan tugas atau kegiatan, apakah sesuai dengan yang semestinya atau tidak. ${ }^{7}$ Pengawasan adalah proses pengamatan daripada pelaksanaan seluruh kegiatan organisasi untuk menjamin agar semua pekerjaan yang sedang dilaksanakan berjalan sesuai dengan rencana yang telah ditentukan sebelumnya. ${ }^{8}$

Menurut Staatblad Tahun 1860 No. 3 mengenai Peraturan Jabatan Notaris Pengertian pengawasan dalam Pasal 50 alinea (1) sampai alinea (3), yaitu tindakan yang dilakukan oleh Pengadilan Negeri berupa peneguran dan/ atau pemecatan selama tiga (3) sampai enam (6) bulan terhadap Notaris yang mengabaikan keluhuran dari martabat atau tugas jabatannya atau melakukan pelanggaran terhadap peraturan umum atau melakukan kesalahan-kesalahan lain, baik di dalam maupun diluar jabatannya sebagai Notaris, yang diajukan oleh penuntut umum pada Pengadilan Negeri pada daerah kedudukannya.

Undang-Undang Nomor 2 Tahun 2014 tentang perubahan atas Undang-Undang 30 Tahun 2004 tentang Jabatan Notaris yang dimaksud dengan pengawasan dalam Penjelasan Pasal 67 ayat (1), yaitu meliputi juga pembinaan yang dilakukan oleh Menteri kepada Notaris. Dalam Pasal 67 ayat (2) dinyatakan bahwa dalam melaksanakan pengawasan menurut Pasal 67 ayat (1) dilakukan oleh Menteri namun dalam pelaksanaannya dilakukan oleh Majelis Pengawas Notaris yang dibentuk oleh Menteri.

Pasal 1 angka (1) Peraturan Menteri Hukum dan Hak Asasi Manusia Republik Indonesia Nomor M.02.PR.08.10 Tahun 2004 menegaskan yang dimaksud dengan pengawasan adalah kegiatan prefentif dan represif termasuk kegiatan pembinaan yang dilakukan oleh Majelis Pengawas terhadap Notaris.

Menurut Keputusan Menteri Kehakiman dan Hak Asasi Manusia Nomor. M-OL.H.T.03.01 Tahun 2003 tentang Kenotarisan

6 Sujamto, 1987, Aspek-Aspek Pengawasan di Indonesia, Sinar Grafika, Bandung, hlm 53.

Ibid, hlm 63

8 Sujamto , 1983, Beberapa Pengertian di Bidang Pengawasan, Ghalia Indonesia, Jakarta, hlm 12. 
Yang dimaksud dengan pengawasan dalam Pasal 1 ayat (8), yaitu kegiatan administratif yang bersifat preventif dan represif oleh Menteri yang bertujuan untuk menjaga agar para Notaris dalam menjalankan jabatannya sesuai dengan peraturan perundang-undangan.

Menurut Keputusan Menteri Hukum dan Hak Asasi Manusia Republik Indonesia Nomor: M.39-PW.07.10 Tahun 2004 tentang Pedoman pelaksanaan Tugas Majelis Pengawas Notaris

Yang dimaksud dengan pengawasan, yaitu pemberian pembinaan dan pengawasan baik secara preventif maupun kuratif kepada Notaris dalam menjalankan profesinya sebagai pejabat umum sehingga Notaris senantiasa harus meningkatkan profesionalisme dan kualitas kerjanya, sehingga dapat memberikan jaminan kepastian dan perlindungan hukum bagi penerima jasa Notaris dan masyarakat luas.

Dari beberapa pengertian tentang pengawasan yang telah disebut di atas maka jelaslah bahwa manfaat pengawasan secara umum adalah untuk mengetahui dan menilai kenyataan yang sebenarnya tentang objek yang diawasi, apakah sesuai dengan yang semestinya atau tidak. Jika dikaitkan dengan masalah penyimpangan, manfaat pengawasan adalah untuk mengetahui terjadi atau tidak terjadinya penyimpangan dan bila terjadi perlu diketahui sebab-sebab terjadinya penyimpangan tersebut. ${ }^{9}$ Selain itu pengawasan berfungsi pula sebagai bahan untuk melakukan perbaikan-perbaikan di waktu yang akan datang, setelah pekerjaan suatu kegiatan dilakukan pengawasan oleh pengawas

Tujuan dari pengawasan yang dilakukan tehadap Notaris adalah supaya Notaris sebanyak mungkin memenuhi persyaratan-persyaratan yang dituntut kepadanya. Persyaratan-persyaratan yang dituntut itu tidak hanya oleh hukum atau undang-undang saja, akan tetapi juga berdasarkan kepercayaan yang diberikan oleh klien terhadap notaris tersebut. Tujuan dari pengawasan itupun tidak hanya ditujukan bagi penataan kode etik Notaris dalam menjalankan tugas jabatannya memenuhi persyaratan-persyaratan yang ditetapkan oleh undang-undang demi pengamanan atas kepentingan masyarakat yang dilayani.

9 Sujamto, op.cit, hlm 64.
Sigian menyatakan bahwa sasaran lain yang perlu dicapai melalui pengawasan selain untuk tujuan efisiensi adalah ${ }^{10}$ :

a. Pelaksanaan tugas-tugas yang telah ditentukan berjalan sungguh-sungguh sesuai dengan pola yang direncanakan

b. Struktur serta hierarki organisasi sesuai dengan pola yang ditentukan dalam rencana

c. Sistem dan prosedur kerja tidak menyimpang dari garis kebijakan yang telah tercermin dalam rencana

d. Tidak terdapat penyimpangan dan atau penyelewengan dalam penggunaan kekuasaan, kedudukan terutama keuntungan.

Pengawasan terhadap Notaris sangat penting bagi kehidupan masyarakat. Dalam menjalankan tugasnya, Notaris ditunut untuk meningkatkan profesionalisme dan kualitas kerjanya, sehingga dapat memberikan jaminan kepastian dan perlindungan hukum bagi klien dan masyarakat luas. Jumlah Notaris yang semakin bertambah tiap tahunnya, mengakibatkan semakin ketatnya persaingan Notaris untuk bersikap professional dan meningkatkan kualitas dirinya.

\section{Pengawasan Majelis Pengawas Daerah terhadap Notaris setelah berlakunya Undang-Undang No. 2 Tahun 2014}

Bertambahnya jumlah Notaris mengakibatkan perlunya pengawasan terhadap kinerja Notaris. sebelum berlakunya Undang-Undang No. 2 tahun 2014 pengawasan dilakukan oleh Pengadilan Negeri setempat. Berdasarkan Pasal 67 ayat (1) Undang-Undang No. 2 Tahun 2014 tentang perubahan atas Undang-Undang No 30 Tahun 2004 tentang Jabatan Notaris :

(1) Pengawasan atas Notaris dilakukan oleh Menteri.

(2) Dalam melaksanakan pengawasan sebagaimana dimaksud pada ayat (1) Menteri membentuk Majelis Pengawas.

(3) Majelis Pengawas sebagaimana dimaksud pada ayat (2) berjumlah 9 (sembilan) orang, terdiri atas unsur:

a. Pemerintah sebanyak 3 (tiga) orang;

b. Organisasi Notaris sebanyak 3 (tiga) orang; dan

c. ahli atau akademisi sebanyak 3 (tiga) orang.

10 Sigian, 2003, "Filsafat Administrasi", Bumi Aksara, Jakarta, hlm 112. 
(4) Dalam hal suatu daerah tidak terdapat unsur instansi pemerintah sebagaimana dimaksud pada ayat (3) huruf a, keanggotaan dalam Majelis Pengawas diisi dari unsur lain yang ditunjuk oleh Menteri.

(5) Pengawasan sebagaimana dimaksud pada ayat (1) meliputi perilaku Notaris dan pelaksanaan jabatan Notaris.

(6) Ketentuan mengenai pengawasan sebagaimana dimaksud pada ayat (5) berlaku bagi Notaris Pengganti dan Pejabat Sementara Notaris

Dalam Pasal 67 memang terjadi perubahan yaitu pada ketentuan ayat (3) dan ayat (6). pada ayat (3) huruf $\mathrm{c}$ terdapat perubahan redaksi sebelumnya adalah ahli/akademisi sebanyak 3 (tiga) orang, setelah perubahan menjadi ahli atau akademisi sebanyak 3(tiga) orang. Dalam ayat (6) Ketentuan mengenai pengawasan sebagaimana dimaksud pada ayat (5) berlaku bagi Notaris Pengganti, Notaris Pengganti Khusus, dan Pejabat Sementara Notaris. Pasal 67 ayat (6) setelah perubahan menjadi Ketentuan mengenai pengawasan sebagaimana dimaksud pada ayat (5) berlaku bagi Notaris Pengganti dan Pejabat Sementara Notaris. Dihilangkannya Notaris pengganti khusus karena dianggap telah tidak sesuai lagi dengan perkembangan di masyarakat sekarang ini. Penjelasan Pasal 67 ayat (1) juga mengalami perubahan dimana di dalam penjelasanya dinyatakan cukup jelas. Sebelumnya, dalam Undang-Undang No. 30 Tahun 2004 tentang Jabatan Notaris penjelasan Pasal 67 ayat ( 1) dinyatakan yang dimaksud dengan "pengawasan" termasuk juga pembinaan terhadap Notaris.

Dalam Pasal 68 Undang-Undang Jabatan Notaris menyebutkan Majelis Pengawas sebagaimana dimaksud dalam Pasal 67 ayat (2) terdiri atas:
a. Majelis Pengawas Daerah;
b. Majelis Pengawas Wilayah; dan
c. Majelis Pengawas Pusat.

Majelis Pengawas Notaris terbagi menjadi 3 yaitu Majelis Pengawas Daerah yang berkedudukan di Kabupaten/Kota, Majelis Pengawas Wilayah berkedudukan di ibu kota Provinsi dan Majelis Pengawas Pusat yang berkedudukan di Ibu Kota Negara.

Dalam ketentuan ayat (1) dan ayat (2) pada Pasal 69 Undang-Undang No 30 Tahun 2004 telah diubah dan di antara ayat (2) dan ayat (3) disisipkan 1 (satu) ayat, yakni ayat (2a) sehingga Pasal 69 Undang-Undang No 2 Tahun 2014 tentang Perubahan atas Undang-Undang No. 30 tahun 2004 berbunyi sebagai berikut:

(1) Majelis Pengawas Daerah dibentuk di Kabupaten/Kota.

(2) Keanggotaan Majelis Pengawas Daerah terdiri atas unsur sebagaimana dimaksud dalam Pasal 67 ayat (3).

(2a) Dalam hal di suatu Kabupaten/Kota, jumlah Notaris tidak sebanding dengan jumlah anggota Majelis Pengawas Daerah, dapat dibentuk Majelis Pengawas Daerah gabungan untuk beberapa Kabupaten/Kota.

(3) Ketua dan Wakil Ketua Majelis Pengawas Daerah dipilih dari dan oleh anggota sebagaimana dimaksud pada ayat (2).

(4) Masa jabatan ketua, wakil ketua, dan anggota Majelis Pengawas Daerah adalah 3 (tiga) tahun dan dapat diangkat kembali.

(5) Majelis Pengawas Daerah dibantu oleh seorang sekretaris atau lebih yang ditunjuk dalam Rapat Majelis Pengawas Daerah.

Pada Pasal 69 ayat (2a) merupakan refleksi dari keadaan pengawasan Notaris selama ini. Sebelum adanya perubahan ini, pengawasan Majelis Pengawas Daerah berdasarkan wilayah kabupaten atau kota. Dalam beberapa daerah yang baru terbentuk ( daerah pemekaran) atau daerah yang tidak banyak Notarisnya, terjadi pemborosan dan tidak adanya efesiensi pengawasan karena anggota Majelis Pengawas Daerah lebih banyak dari jumlah Notaris yang di awasi. Misalnya, dalam 1 kabupaten hanya ada 2 Notaris, sedangkan jumlah Majelis Pengawas Daerah ada 9 orang. Untuk menghemat biaya pengawasan dan efisiensi pengawasan maka dirasa perlu untuk penggabungan beberapa wilayah kabupaten/Kota.

Pada Pasal 70 mengenai kewenangan Majelis Pengawas Daerah terhadap pengawasan Notaris tidak mengalami perubahan. Pasal 70 menyatakan Majelis Pengawas Daerah berwenang:

a. Menyelenggarakan sidang untuk. memeriksa adanya dugaan pelanggaran Kode Etik Notaris atau pelanggaran pelaksanaan jabatan Notaris;

b. Melakukan pemeriksaan; terhadap Protokol Notaris secara berkala 1 (satu) kali dalam 1 (satu) tahun atau setiap waktu yang dianggap perlu; 
c. Memberikan izin cuti untuk waktu sampai dengan 6 (enam) bulan;

d. Menetapkan Notaris Pengganti dengan memperhatikan usul Notaris yang bersangkutan;

e. Menentukan tempat penyimpanan Protokol Notaris yang pada saat serah terima Protokol Notaris telah berumur 25 (dua puluh lima) tahun atau lebih;

f. Menunjuk Notaris yang akan bertindak sebagai pemegang sementara Protokol Notaris yang diangkat sebagai pejabat negara sebagaimana dimaksud dalam Pasal 11 ayat (4);

g. Menerima laporan dari masyarakat mengenai adanya dugaan pelanggaran Kode Etik Notaris atau pelanggaran ketentuan dalam Undang-Undang ini; dan

h. Membuat dan menyampaikan laporan sebagaimana dimaksud pada huruf a, huruf $b$, huruf c, huruf d, huruf e, huruf $f$, dan huruf g kepada Majelis Pengawas Wilayah.

Berdasarkan ketentuan Pasal 70 ini Majelis Pengawas Daerah melakukan Pengawasan terhadap Jabatan Notaris juga perilaku Notaris yang diatur di dalam Kode Etik Profesi Notaris. Majelis Pengawas Daerah memberikan izin cuti kepada Notaris yang permohonan izin cuti tidak melebihi waktu 6 (enam)bulan. Majelis Pengawas Daerah menetapkan Notaris pengganti dengan memperhatikan usul Notaris. Majelis Pengawas Daerah juga menentukan tempat protocol Notaris, dan menunjuk Notaris pemegang sementara Protokol Notaris. Majelis Pengawas Daerah melakukan pengawasan terhadap adanya laporan dari masyarakat mengenai adanya dugaan pelanggaran Kode Etik Notaris atau pelanggaran ketentuan Undang-Undang Jabatan Notaris.

Pasal 71 mengenai kewajiban Majelis Pengawas Daerah juga tidak mengalami perubahan. Pasal 71 menyebutkan Majelis Pengawas Daerah berkewajiban:

a. Mencatat pada buku daftar yang termasuk dalam Protokol Notaris dengan menyebutkan tanggal pemeriksaan, jumlah akta serta jumlah surat di bawah tangan yang disahkan dan yang dibuat sejak tanggal pemeriksaan terakhir;

b. Membuat berita acara pemeriksaan dan menyampaikannya kepada Majelis Pengawas Wilayah setempat, dengan tembusan kepada Notaris yang bersangkutan, Organisasi Notaris, dan Majelis Pengawas Pusat;

c. Merahasiakan isi akta dan hasil pemeriksaan;

d. Menerima salinan yang telah disahkan dari daftar akta dan daftar lain dari Notaris dan merahasiakannya;

e. Memeriksa laporan masyarakat terhadap Notaris dan menyampaikan hasil pemeriksaan tersebut kepada Majelis Pengawas Wilayah dalam waktu 30 (tiga puluh) hari, dengan tembusan kepada pihak yang melaporkan, Notaris yang bersangkutan, Majelis Pengawas Pusat, dan Organisasi Notaris.

f. Menyampaikan permohonan banding terhadap keputusan penolakan cuti.

Dalam Undang-Undang No.2 Tahun 2004 tentang Perubahan atas Undang-Undang No. 30 Tahun 2004 tentang Jabatan Notaris juga terdapat perubahan beberapa kewenangan Majelis Pengawas Daerah yang dimana kewenangan tersebut menjadi sebuah kewenangan lembaga yang baru yaitu Majelis Kehormatan Notaris . Pada Bab VIII diubah, penyebutannya menjadi pengambilan fotocopy minuta akta dan pemanggilan notaris, yang sebelumnya hanya memuat tulisan pengambilan minuta akta dan pemanggilan notaris. Notaris tidak bisa menyerahkan minuta akta (asli akta) kepada orang lain kecuali para pihak yang bertanda tangan di dalam akta itu karena akan bertentangan dengan kewenangan dan sumpah jabatan Notaris. Dalam hal diperlukannya proses persidangan yang bisa diserahkan hanyalah fotocpy minuta akta.

Ketentuan Pasal 66 ayat (1) diubah dan ditambah 2 (dua) ayat, yakni ayat (3) dan ayat (4) sehingga Pasal 66 berbunyi sebagai berikut:

(1) Untuk kepentingan proses peradilan, penyidik, penuntut umum, atau hakim dengan persetujuan Majelis Kehormatan Notaris berwenang:

a. Mengambil fotokopi Minuta Akta dan/atau surat-surat yang dilekatkan pada Minuta Akta atau Protokol Notaris dalam penyimpanan Notaris; dan

b. Memanggil Notaris untuk hadir dalam pemeriksaan yang berkaitan dengan Akta atau Protokol Notaris yang berada dalam penyimpanan Notaris. 
(2) Pengambilan fotokopi Minuta Akta atau surat-surat sebagaimana dimaksud pada ayat (1) huruf a, dibuat berita acara penyerahan.

(3) Majelis kehormatan Notaris dalam waktu paling lama 30 (tiga puluh) hari kerja terhitung sejak diterimanya surat permintaan persetujuan sebagaimana dimaksud pada ayat (1) wajib memberikan jawaban menerima atau menolak permintaan persetujuan.

(4) Dalam hal majelis kehormatan Notaris tidak memberikan jawaban dalam jangka waktu sebagaimana dimaksud pada ayat (3), majelis kehormatan Notaris dianggap menerima permintaan persetujuan.

Perubahan Pasal 66 tersebut adalah akibat dari putusan Majelis Mahkamah Konstitusi (MK), dengan Putusan MK No. 49/PUUX/2012 tanggal 23 Maret 2013, telah mengabulkan permohonan uji materiil (judicial review) terhadap Pasal 66 (ayat (1) UU No.30 Tahun 2004 tentang Jabatan Notaris yang diajukan Sdr Kant Kamal. Amar putusan MK pada intinya membatalkan frasa dengan persetujuan Majelis Pengawas Daerah (MPD) dalam pasal yang diuji. Dengan demikian pemeriksaan proses hukum yang melibatkan notaris tidak memerlukan persetujuan MPD lagi dan frasa tersebut dianggap bertentangan dengan UUD 1945 dan tidak memiliki kekuatan hukum mengikat. Keputusan ini final and binding dan harus ditaati.

Pasal 66 dalam Undang-Undang No 30 Tahun 2004 tentang Jabatan Notaris (sebelum perubahan) menyatakan bahwa :

(1) Untuk kepentingan proses peradilan, penyidik, penuntut umum, atau hakim dengan persetujuan Majelis Pengawas Daerah berwenang:

a. Mengambil fotokopi Minuta Akta dan/atau surat-surat yang dilekatkan pada Minuta Akta atau Protokol Notaris dalam penyimpanan Notaris; dan

b. Memanggil Notaris untuk hadir dalam pemeriksaan yang berkaitan dengan akta yang dibuatnya atau Protokol Notaris yang berada dalam penyimpanan Notaris.

Sebelum Putusan MK tersebut, Notaris tidak bisa langsung ke dalam proses peradilan, menghadap penyidik, penuntut umum atau hakim tanpa adanya persetujuan Majelis Pengawas Daerah. Putusan MK tersebut cukup menghentak dunia Notaris yang saat ini merasa mendapat perlindungan frasa tersebut. Penegak hukum terutama polisi tidak boleh serta-merta demi proses peradilan pidana mengambil dokumen dalam penyimpanan Notaris dan memanggil Notaris untuk hadir dalam pemeriksaan yang bersentuhan dengan dokumen-dokumen yang dibuatnya, tanpa persetujuan MPD.

Pasal 66 Undang-Undang No 30 Tahun 2004 tersebut dianggap melanggar prinsip persamaan di depan hukum (equality before the law) yang tersurat dan tersirat dalam Pasal 28 ayat (1) UUD 1945 yang bersifat universal sesuai pula dengan Article 26 ICCPR (International Covenant on Civiland Political Rights) 1966 yang juga sudah diratifikasi oleh Indonesia dengan UU No.12/2005. Di sini ditegaskan adanya persamaan kedudukan semua orang di depan hukum dan hak semua orang atas perlindungan hukum yang sama (equal protection) tanpa diskriminasi.

Menurut MK, ada suatu prinsip demokrasi dan rule of law yang dapat dicederai dengan frasa di atas, yaitu kekuasaan kehakiman yang merdeka (independence of the judiciary), yang harus dikawal oleh MK dan Mahkamah Agung (MA). Campur tangan MPD juga dianggap dapat menimbulkan penundaan proses peradilan dan keadilan (justice delayed justice denied). Sementara penundaan keadilan juga melanggar HAM (delay of justice is violation of buman rights). Perkecualian tentu saja dimungkinkan terhadap kedudukan Notaris sepanjang berkaitan dengan Kode Etik Notaris yang bersentuhan dengan sikap, tingkah laku dan moralitas serta kehormatan (dignity) Notaris, bukan dalam penegakan hukum, khususnya sistem peradilan pidana (criminal justice system). Gangguan terhadap kekuasaan kehakiman yang merdeka dan bersifat universal bisa menimbulkan ketidakadilan (criminal injustice system).

Kewenangan memberikan persetujuan pemanggilan Notaris tidak bisa dilaksanakan lagi oleh Majelis Pengawas Daerah karena adanya Putusan MK No. 49/PUU-X/2012. Setelah Undang-Undang No 2 Tahun 2014 ini disahkan frase mendapatkan persetujuan tersebut kembali muncul di dalam Pasal 66 dengan lembaga yang berbeda yaitu Majelis Kehormatan Notaris.

Berdasarkan perubahan Pasal 66 tersebut dimana kewenangan Majelis Pengawas Daerah dalam memberikan persetujuan terhadap pemerikasaan Notaris oleh penegak hukum tidak 
berlaku lagi dan menjadi kewenangan Majelis Kehormatan Notaris sesuai dengan Pasal 66 Undang-Undang No 2 Tahun 2014, maka di antara Pasal 66 dan Pasal 67 disisipkan 1 (satu) pasal, yakni Pasal 66A yang mengatur tentang Majelis Kehormatan Notaris.

Pasal 66A menyatakan :

(1) Dalam melaksanakan pembinaan, Menteri membentuk Majelis Kehormatan Notaris.

(2) Majelis Kehormatan Notaris berjumlah 7 (tujuh) orang, terdiri atas unsur:

a. Notaris sebanyak 3 (tiga) orang;

b. Pemerintah sebanyak 2 (dua) orang; dan

c. Ahli atau akademisi sebanyak 2 (dua) orang.

(3) Ketentuan lebih lanjut mengenai tugas dan fungsi, syarat dan tata cara pengangkatan dan pemberhentian, struktur organisasi, tata kerja, dan anggaran majelis kehormatan Notaris diatur dengan Peraturan Menteri.

Pasal 66A mengatur secara khusus mengenai sebuah lembaga baru yaitu Majelis Kehormatan Notaris. Majelis Kehormatan Notaris merupakan lembaga pembinaan terhadap Notaris yang sebelumnya ada pada Majelis Pengawas Daerah. Jumlah anggota Notaris adalah 3 (tiga) orang, pemerintah 2 (dua) orang, dan ahli atau akademisi sebanyak 2(dua) orang. Dalam pembinaan ini unsur Notaris lebih banyak di banding unsur pemerintah dan ahli atau akademisi, karena dalam proses pembinaan Notaris lebih mengetahui profesinya.

Dalam Peraturan Menteri Hukum dan Hak Asasi Manusia Republik Indonesia Nomor : M.02.PR.08.10 Tahun 2004 tentang Tata Cara Pengangkatan Anggota, Pemberhentian Anggota, Susunan Organisasi, Tata Kerja, dan Tata Cara Pemeriksaan Majelis Pengawas Notaris, pengawasan adalah kegiatan yang bersifat preventif dan represif termasuk kegiatan pembinaan yang dilakukan oleh Majelis Pengawas terhadap Notaris.

Mekanisme pengawasan yang dilakukan terhadap pelaksanaan tugas dan jabatan Notaris adalah bersifat preventif maupun represif. Pengawasan yang dilakukan secara preventif adalah pengawasan yang dilakukan sebelum pelaksanaan, yang berarti pengawasan terhadap segala sesuatu yang masih bersifat rencana sedangkan pengawasan yang dilakukan secara represif adalah pengawasan yang dilakukan setelah pekerjaan atau kegiatan dilaksanakan.

Tujuan dari adanya pelaksanaan tugas dan wewenang Majelis Pengawas Notaris adalah memberikan arah dan tuntunan bagi anggota Majelis Pengawas Notaris dalam menjalankan tugasnya, agar dapat memberikan pembinaan dan juga pengawasan kepada Notaris dalam menjalankan jabatan profesinya sebagai pejabat umum, senantiasa meningkatkan profesionalisme dan kualitas kerjanya, sehingga dapat memberikan jaminan kepastian dan perlindungan hukum bagi penerima jasa Notaris, karena adanya Notaris bukanlah untuk kepentingan Notaris itu sendiri tetapi untuk kepentingan masyarakat yang dilayani atau meminta jasa Notaris.

Peran Majelis Pengawas Daerah yang sebelumnya melakukan pengawasan dan pembinaan, setelah Undang-Undang No. 2 Tahun 2014 ini diberlakukan menjadi terpisah yaitu oleh Majelis Pengawas Daerah dan Majelis Kehormatan Notaris. Pembinaan oleh Majelis Kehormatan Notaris diatur di dalam Pasal 66A, sedangkan pengawasan dilakukan oleh Majelis Pengawas Daerah yang diatur dalam Pasal 67. Sampai tulisan ini dibuat mengenai tugas dan fungsi dan tata cara pengangkatan dan pemberhentian, struktur organisasi, tata kerja dan anggaran majelis kehormatan Notaris berdasarkan Pasal 66A ayat (3) belum di atur dengan Peraturan Menteri.

Majelis Pengawas Daerah tidak mempunyai kewenangan untuk menjatuhkan sanksi apapun. Meskipun Majelis Pengawas Daerah mempunyai wewenang untuk menerima laporan dari masyarakat dan dari Notaris lainnya dan menyelenggarakan sidang untuk memeriksa adanya dugaan pelanggaran pelaksanaan jabatan Notaris, tapi tidak diberi kewenangan untuk menjatuhkan sanksi apapun. Majelis Pengawas Daerah hanya berwenang untuk melaporkan hasil sidang dan pemeriksaannya kepada Majelis Pengawas Wilayah dengan tembusan kepada pihak yang melaporkan, Notaris yang bersangkutan, Majelis Pengawas Pusat dan Organisasi Notaris (INI).

\section{Kesimpulan}

1. Pengawasan Majelis Pengawas Daerah terhadap Notaris meliputi jabatan Notaris dan perilaku Notaris. Pengawasan terhadap jabatan Notaris meliputi kewajiban dan kewenangannya sebagai Notaris berdasarkan 
Undang-Undang Jabatan Notaris, sedangkan pengawasan perilaku Notaris berdasarkan Kode Etik Notaris.

2. Setelah diberlakukannya Undang-Undang Nomor 2 Tahun 2014 tentang perubahan atas Undang-Undang Nomor 30 Tahun 2004 tentang Jabatan Notaris, terdapat beberapa perubahan terhadap ketentuan yang mengatur Majelis Pengawas Daerah. Kewenangan dan Kewajiban Majelis Pengawas Daerah dalam hal pengawasan terhadap Notaris tidak mengalami perubahan. Perubahan terjadi dalam hal pembinaan terhadap Notaris. Pembinaan yang sebelumnya merupakan kewenangan Majelis Pengawas Daerah sekarang menjadi kewenangan Majelis Kehormatan Notaris.

\section{Saran}

1. Dalam Pasal 1 mengenai ketentuan umum hanya memuat ketentuan mengenai pengertian Majelis Pengawas Daerah, tetapi belum memuat ketentuan mengenai pengertian dari Majelis Kehormatan Notaris. Pengertian ini menjadi penting agar masyarakat dapat membedakan fungsi dari 2 (dua) lembaga ini.

2. Pemerintah dalam hal ini Kementrian Hukum dan HAM harus segera mengeluarkan Peraturan Menteri yang mengatur Majelis Pengawas Daerah dan Majelis Kehormatan Notaris, agar tidak terjadi tumpang tindih pengawasan terhadap Notaris.

\section{Daftar Rujukan \\ Buku-buku}

Adam, Muhammad, 1985, Asal Usul dan Sejarah Notaris, Sinar Bakti , Bandung

Andasasmita, Komar, 1983, Notaris Selayang Pandang, Cet. 2Alumni, Bandung

\section{Bandung}

Komar, 1981, Notaris I, Sumur,

Adjie, Habib, 2008, Sanksi Perdata dan Administratif Terbadap Notaris Sebagai Pejabat Publik, Refika Aditama, Bandung 2008, Hukum Notaris Indonesia, Tafsir Tematik Terbadap UU No. 30
Tabun 2004 Tentang Jabatan Notaris, PT Refika Aditama, Bandung

Anshori, Abdul Ghofur, 2009, Lembaga Kenotariatan Indonesia: Perspektif Hukum dan Etika/Profesi, UII Press, Yogyakarta

Fatahna ,Muclis dan Joko 2003, Notaris Bicara Soal Kenegaraan,Watampone Press, Jakarta

HR, Ridwan, 2002, Hukum Administrasi Negara, Rajawali Press, Jakarta

Koentjoro, Diana Hakim, 2004, Hukum Administrasi Negara, Ghalia Indonesia. Bogor

Saputro, Anke Dwi 2009, "Jati Diri Notaris Indonesia Dulu, Sekarang dan Dimasa Datang", Gramedia Pustaka, Jakarta

Sigian, 2003, "Filsafat Administrasi", Bumi Aksara, Jakarta

Situmorang, Viktor M dan Cormentyna Sitanggang, 1993, Hukum Administrasi Pemerintaban di Daerah, Sinar Grafika, Bandung

Sujamto , 1983, Beberapa Pengertian di Bidang Pengawasan, Ghalia Indonesia, Jakarta

1987, Aspek-Aspek Pengawasan di Indonesia, Sinar Grafika, Bandung

Tan Thong, Kie, 2000, Buku I Studi Notariat Serba Serbi Praktek Notaris, Cet. 2, Ichtiar Baru Van Hoeve, Jakarta

Tobing, GHS Lumban, 1983, Peraturan Jabatan Notaris, cet.III, Erlangga, Jakarta

G.H.S. Lumban, 1999, Peraturan Jabatan Notaris, Cet. 5, Airlangga, Jakarta

Untung, Budi, 2001, Visi Global Notaris, Andi, Yogyakarta, 2001

\section{MAJALAH}

Renvoi, Majalah Nomor 3.15.11, tanggal 3 Agustus 2004 